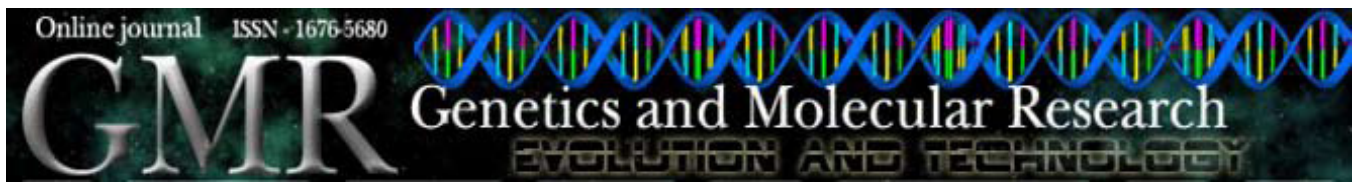

\title{
RAPD analysis of selected local Turkish grape cultivars (Vitis vinifera)
}

\author{
H. Karataş ${ }^{1}$ and Y.S. A $\breve{g a o g ̆ l u}{ }^{2}$ \\ ${ }^{1}$ Dicle University, Faculty of Agriculture, \\ Department of Horticulture, Diyarbakır, Turkey \\ ${ }^{2}$ Ankara University, Faculty of Agriculture, \\ Department of Horticulture, Dışkapı, Ankara, Turkey \\ Corresponding author: H. Karataş \\ E-mail: hkaratas@dicle.edu.tr / karatas2172@yahoo.com
}

Genet. Mol. Res. 9 (4): 1980-1986 (2010)

Received May 20, 2010

Accepted July 19, 2010

Published October 5, 2010

DOI 10.4238/vol9-4gmr926

\begin{abstract}
Turkey is very rich in local grape varieties. The solution to the problem of identifying local cultivars, which is considered an important deficiency for the region, will only be possible when they can be defined with molecular markers. Forty-nine local grapevine cultivars from Şanliurfa (Turkey) were characterized with RAPD markers. Twenty-five decamer primers selected from 60 primers were used in this analysis. A total of 171 bands were obtained with the 25 primers, of which 112 were polymorphic; the level of DNA polymorphism was $65.49 \%$ in these local cultivars. Among the selected primers, OPA-18, OPO-07 and P-123 gave the maximum number of polymorphic bands (seven). Genetic relationships among these cultivars were determined with a similarity index and using a dendogram. Among the grape cultivars, the lowest similarity ratio (0.578) was observed among the Külahi-Kızılbanki cultivars and the highest similarity ratio $(0.908)$ was observed for the ÇilorutDökülgen combination. The high similarity ratio among the grape cultivars of Şanliurfa Province was also reflected in the dendogram.
\end{abstract}


In general, no relationships were encountered between the genetic identification of the cultivars and their ampelographic properties.

Key words: Vitis vinifera L.; Molecular characterization; RAPD; Similarity index; Dendogram

\section{INTRODUCTION}

Grapevine (Vitis vinifera L.) is one of the oldest and most important perennial crops in the world. Turkey is an important center of origin of the cultivated grapevine $V$. vinifera $\mathrm{L}$. Cultivation of grapes in Anatolia began approximately 7-8000 years ago and seeds of domesticated grapes dating from ca. 8000 BP have also been found in the region (Arroyo Garcia et al., 2006; This et al., 2006). In Turkey with its large grape germplasm, so far, approximately 1200 cultivars, including synonymous cultivars, have been transferred from the different ecological zones of the country to the National Germplasm Repository Vineyard in Tekirdağ (Ergül and Ağaoğlu, 2001).

Turkey is very rich in local grape varieties. The naming of local grapevines is a major problem in Turkish viticulture. There are many grape cultivars with similar morphological characters, which are cultivated in different locations under different names in Anatolia. There is much confusion about the names of the grape cultivars grown in this province, which has a very rich history of different civilizations and societies. The solution to the problem of the existence of cultivars, which is considered an important deficiency for the region, is only possible by creating genetic definitions for all the cultivars with molecular markers [random amplified polymorphic DNA (RAPD), amplified fragment length polymorphism (AFLP), simple sequence repeats (SSR), etc.].

The RAPD technique is fast and easy, since it does not require knowledge of the sequences of the markers and can produce abundant polymorphic fragments. RAPD analysis is one of the techniques that has been used successfully to reveal genetic variations (Kocsis et al., 2005). Notwithstanding the limitations, RAPD markers have proven to be a highly effective and efficient method for the genetic analysis (Gogorcena et al., 1993; Büscher et al., 1994; Ye et al., 1998; Vidal et al., 1999; Luo et al., 2002; Ulanovsky et al., 2002). Large numbers of data sets can be generated because different RAPD primers are commercially available (Fanizza et al., 2000).

The objective of this study was to identify the 49 local (Şanlıurfa-Turkey) grape cultivars. This study presents the genotyping of local (Şanlıurfa) grapevine cultivars, using the RAPD-PCR (polymerase chain reaction) technique. The determination of genetic diversity and relationships between cultivars, as well as the application of the data obtained for cultivar identification, are discussed.

\section{MATERIAL AND METHODS}

\section{Plant material}

Forty-nine local grapevine cultivars ( $V$. vinifera L.) were studied for characterization. Forty genotypes of these plant samples were taken from vineyards in the Turkish city of Şanliurfa. Nine genotype samples were taken from the National Germplasm Repository Vineyard of Tekirdağ. The cultivars used in this study are listed in Table 1. 


\begin{tabular}{|c|c|c|c|c|}
\hline $\mathrm{N}$ & Cultivar name & Collection & Berry color & Use (table/raisin/wine) \\
\hline 1 & Hönüsü & Ş & Red & Table \\
\hline 2 & Şire & Ş & White & Wine \\
\hline 3 & Sergi karası & Ş & Red & Raisin \\
\hline 4 & Cibin & Ş & Red & Raisin \\
\hline 5 & Tilgören & Ş & Red & Table, Wine \\
\hline 6 & Çiloreş & Ş & White & Table, Wine \\
\hline 7 & Çilorut & Ş & White & Table, Wine \\
\hline 8 & Simore & Ş & White & Table, Wine \\
\hline 9 & Gülgülü & Ş & Pink & Table, Wine \\
\hline 10 & Zeyni & Ş & White & Table, Wine \\
\hline 11 & Tahannebi & Ş & White & Table \\
\hline 12 & Zeynebi & Ş & White & Table, Raisin \\
\hline 13 & Bastıkkabarcığ1 & Ş & White & Wine \\
\hline 14 & Kabarcık & Ş & White & Wine \\
\hline 15 & Külahi & Ş & White & Table \\
\hline 16 & Yediveren-a* & Ş & Red & Table, Wine \\
\hline 17 & Horoz karası & Ş & Red & Table, Wine, Raisin \\
\hline 18 & Hatunparmağı (white) & Ş & White & Table, Raisin \\
\hline 19 & Azezi & Ş & White & Table, Wine \\
\hline 20 & Kay1s1 & Ş & White & Table \\
\hline 21 & Şarabi & Ş & Red & Wine \\
\hline 22 & Danaburnu & Ş & Red & Table, Wine \\
\hline 23 & Keçiemceği & Ş & Red & Raisin \\
\hline 24 & Dımışk1 & Ş & White & Table, Raisin \\
\hline 25 & Muhammediye & Ş & White & Table \\
\hline 26 & Yediveren-b* & Ş & Red & Table, Wine \\
\hline 27 & Hatunparmağ (black) & Ş & Red & Table, Raisin \\
\hline 28 & Elmaüzümü & Ş & White & Table, Wine \\
\hline 29 & Karamikeri & Ş & Red & Table \\
\hline 30 & Köseni & Ş & Pink & Table \\
\hline 31 & Çördüğüü & Ş & White & Table, Wine \\
\hline 32 & Serpenekıran & Ş & White & Table, Wine \\
\hline 33 & Halebi & Ş & White & Table, Wine \\
\hline 34 & Avderi & Ş & White & Table, Wine \\
\hline 35 & Kızılbanki & SS & Pink & Table \\
\hline 36 & Antepüzümü & Ş & Red & Table \\
\hline 37 & Dusuzu & Ş & White & Wine \\
\hline 38 & Siyahüzüm & Ş & Red & Wine \\
\hline 39 & Kizlartahtas1 & Ş & White & Table, Wine \\
\hline 40 & Şefafi & Ş & White & Wine \\
\hline 41 & Simore* & T-Ş & White & Wine \\
\hline 42 & Çilorut* & T-Ş & White & Wine \\
\hline 43 & Siverek* & T-Ş & White & Wine \\
\hline 44 & Ruhali* & T-Ş & White & Table \\
\hline 45 & Tilgören* & $\mathrm{T}-\widehat{s}$ & Red & Wine \\
\hline 46 & Kay1s1* & $\mathrm{T}-\mathrm{S}$ & White & Table \\
\hline 47 & Zerik* & $\mathrm{T}-\widehat{S}$ & White & Raisin \\
\hline 48 & Çiloreş* & T-Ş & White & Table, Wine \\
\hline 49 & Çörtük* & $\mathrm{T}$-Ş & White & Table \\
\hline
\end{tabular}

Ş = Şanlıurfa; T-Ş = National Germplasm Repository Vineyard samples that were previously brought from Şanliurfa. *Yediveren-a = for vineyard type; Yediveren- $b=$ for pergola trellis type.

\section{DNA extraction}

DNA from young, healthy leaves was extracted following the protocol of Lodhi et al. (1994). DNA concentration and purity were measured using a NanoDrop ND-1000 model spectrophotometer. An initial screening with 60 primers (10-mers) from the kits OPA, OPB, OPF, OPD, UBC, P, B, and S from Operon Technologics Inc. (Huntsville, AL, USA) was carried out on 5 cultivars. Only 25 informative primers were selected due to their ability to 
produce polymorphic, unambiguous and stable RAPD markers.

\section{RAPD analysis and gel electrophoresis}

RAPD amplification was performed in a $25-\mu \mathrm{L}$ reaction volume containing $200 \mathrm{ng}$ genomic DNA, 10X buffer ( $25 \mathrm{mM} \mathrm{MgCl}, 2.5 \mathrm{mM}$ dNTPs, 200 ng primer (Operon Technologics Inc.), and 0.3 U Tag DNA polymerase (Promega, Madison, WI, USA). The thermocycler was programmed as follows; initial cycle of $5 \mathrm{~min}$ at $94^{\circ} \mathrm{C}$ followed by 35 cycles of $30 \mathrm{~s}$ at $94^{\circ} \mathrm{C}$, an annealing temperature of $30^{\circ}$ to $38^{\circ} \mathrm{C}$ for $1 \mathrm{~min}$, elongation step of $1 \mathrm{~min} 45 \mathrm{~s}$ at $72^{\circ} \mathrm{C}$, and a final extension step of $8 \mathrm{~min}$ at $72^{\circ} \mathrm{C}$.

PCR products were separated by gel electrophoresis on $1.5 \%$ agarose gels with $1 \mathrm{X}$ TBE (Trisma base, boric acid, EDTA) buffer, using a volt range of $100 \mathrm{~V} / \mathrm{cm}$ for $4 \mathrm{~h}$. The gel was stained with $0.25 \mu \mathrm{g} / \mathrm{mL}$ ethidium bromide and photographed black and white on Polaroid type 665 film. RAPDs have often been criticized for low reproducibility; in order to avoid this phenomenon we used highly constant conditions and all reactions were repeated at least twice (Kocsis et al., 2005).

\section{Data analysis}

In order to ensure the absence of artifacts, bands were carefully selected from replicated amplifications. Amplified bands were designed by their primer code and their size in base pairs. Data were recorded as discrete variables: 1 for the presence and 0 for the absence of a similar band. Only intense and reproducible bands appearing on the gel were scored. Jaccard's coefficient was used to calculate the genetic distance (Dps) between cultivars. However, the MVSP software (Kowach, 1999) was used to calculate the similarity index. These indices were converted into a dendogram by using "UPGMA" cluster.

\section{RESULTS AND DISCUSSION}

Forty-nine local cultivars were studied by RAPD markers for genotyping studies. Twenty-five informative primers were selected and used due to their ability to produce polymorphic RAPD markers. According to This et al. (1997), some primers seem to be more efficient than others in producing stable and reproducible DNA fingerprints.

A total of 171 bands were evaluated from the 25 primers used; 112 polymorphic bands were found and the level of DNA polymorphism established among local cultivars was $65.49 \%$. From the selected primers OPA-18, OPO-07 and P-123, the maximum number of polymorphic ( 7 bands) bands were produced. The lowest number of polymorphic bands ( 3 bands) was obtained using OPA-01, OPA-04, OPA-07, OPA-15, OPF-08, OPO-11, P-437 primers. When the ratios of polymorphic bands are examined on the basis of primers, the highest ratio $(87.50 \%)$ was determined with OPA-18 and P-123 and the lowest ratio (37.50\%) was obtained with OPF-08.

Figure 1 shows the sample gel images of RAPD patterns obtained with primer P-166.

Primer selection is essential for discrimination analysis. Obviously, the more bands scored and plants studied, the higher the statistical significance of the calculation will be. About 100 bands should be enough to obtain statistically significant results (Kocsis et al., 2005).

When the dendogram determining the rate of relativity between genotypes on the basis of coefficient of similarity was examined, it was observed that the similarity ratio among 
the local grape cultivars of Şanliurfa Province was high. The dendogram generated by RAPD analysis showed 5 distinct groups $(1=3$ cultivars; $2=5$ cultivars; $3=20$ cultivars; $4=8$ cultivars, and $5=4$ cultivars; Figure 2).

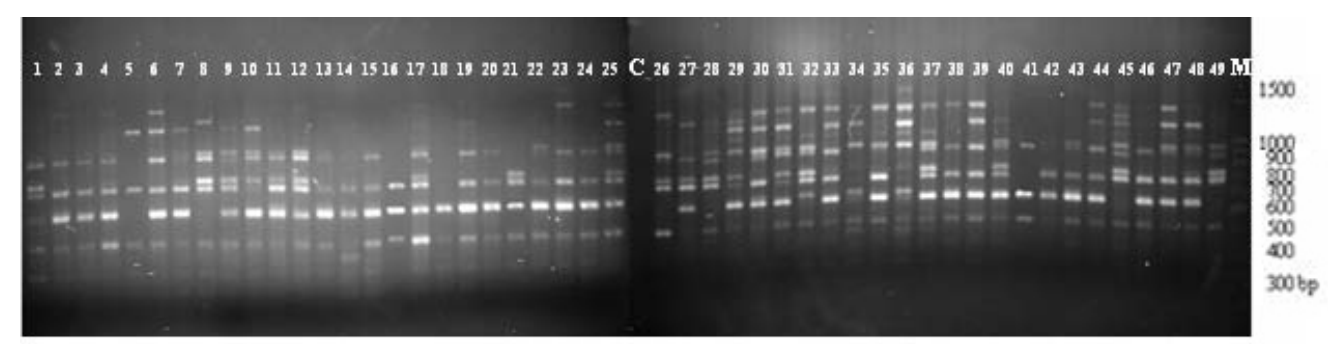

Figure 1. RAPD profiles of leaf extracts of grapevine cultivars from Şanliurfa Province using primer P 166 [M = molecular marker - 100-bp DNA ladder (Promega)] C: Control. Lane 1 = Hönüsü; lane 2 = Şire; lane 3 = Sergi karas1; lane 4 =Cibin; lane $5=$ Tilgören; lane $6=$ Çiloreş; lane $7=$ Çilorut; lane $8=$ Simore; lane $9=$ Gülgülü; lane $10=$ Zeyni; lane 11 = Tahannebbi; lane 12 = Zeynebi; lane 13 = Bastıkkabarcığ1; lane $14=$ Kabarcık; lane $15=$ Külahi; lane $16=$ Yediveren-a; lane $17=$ Horoz karas1; lane $18=$ Hatunparmağ 1 (white); lane $19=$ Azezi; lane $20=$ Kayıs1; lane 21 = Şarabi; lane 22 = Danaburnu; lane $23=$ Keçiemceği; lane $24=$ Dımışk1; lane $25=$ Muhammediye; lane $26=$ Yediveren-b; lane 27= Hatunparmağ (black); lane $28=$ Elmaüzümü; lane $29=$ Karamikeri; lane $30=$ Köseni; lane $31=$ Çördüğ̈̈; lane 32 = Serpenekıaran; lane $33=$ Halebi; lane $34=$ Avderi; lane $35=$ Kızllbanki; lane $36=$ Antepüzümü; lane $37=$ Dusuzu; lane $38=$ Siyahüzüm; lane $39=$ Kılartahtasi; lane $40=$ Şefafi; lane $41=$ Simore*; lane $42=$ Çilorut*; lane 43 = Siverek*; lane $44=$ Ruhali*; lane $45=$ Tilgören*; lane $46=$ Kayısı*; lane $47=$ Zerik*; lane $48=$ Çiloreş*; lane 49 $=$ Çörtük*. ${ }^{*}$ Cultivars collected from the National Germplasm Repository Vineyard in Tekirdağ Province.

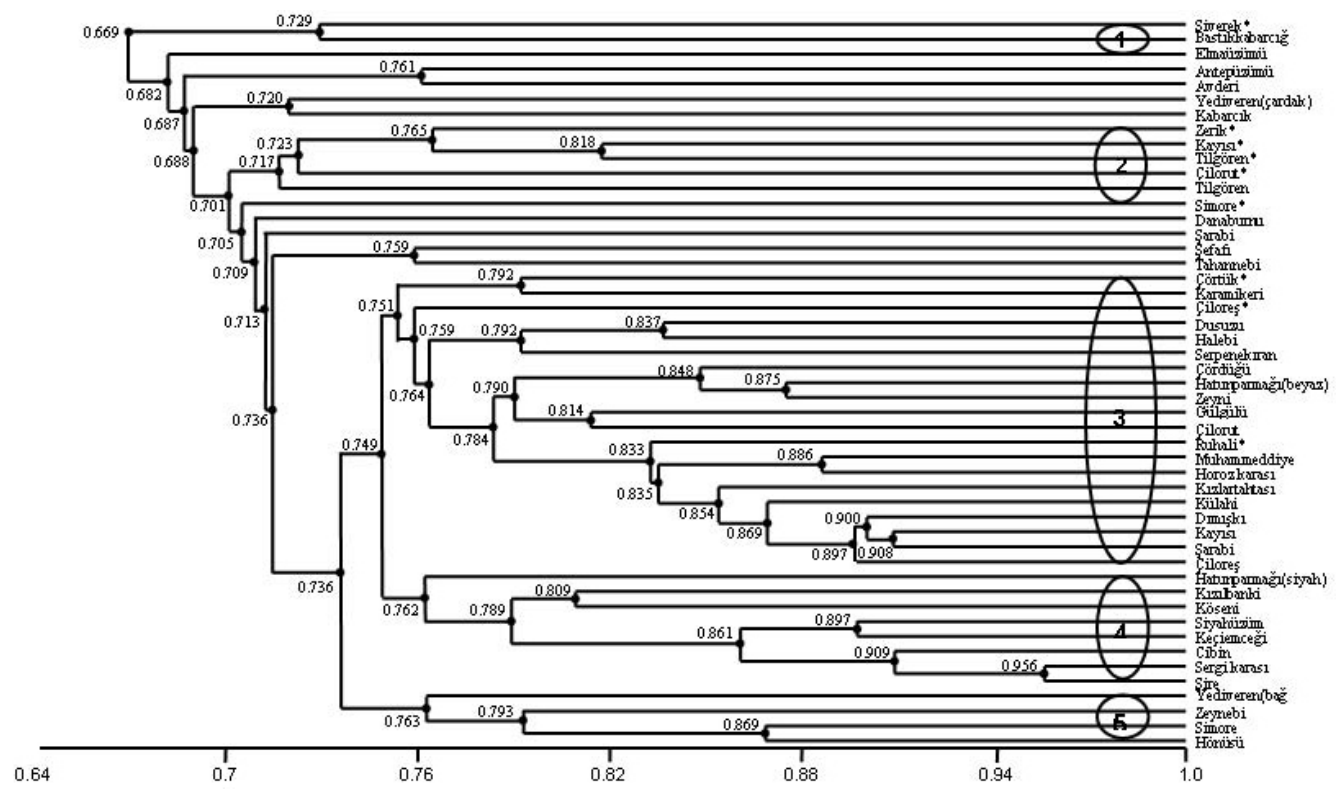

Figure 2. Dendogram of 49 grape cultivars based on similarity index from RAPD data, showing the genetic relationships of tested cultivars. *Cultivars collected from Tekirdağ (National Germplasm Repository Vinevard of Tekirdağ). 
The values of genetic distance ranged from 0.578 for the most closely related cultivars (Külahi-Kızılbanki) to 0.908 for the most distantly related cultivars (Çilorut-Dökülgen).

In this study, the general similarity ratios among the cultivars were found to be between 0.650 and 0.900 , showing a parallelism with the other RAPD analyses performed by other researchers, 0.553-0.952 (Ergül et al., 2002; Karataş, 2005; Ağaoğlu et al., 2006; Karataş and Ağaoğlu, 2008).

The similarity ratios of the grape cultivars obtained from Tekirdağ and the grapes with the same name obtained from Şanlıurfa Province are given below. Despite the fact that there is a high similarity ratio among them, they are different from each other. RAPD analyses determined that the grape cultivars grown in Şanlıurfa Province have a rich gene source in Turkey and the cultivars transferred to the National Germplasm Repository Vineyard of Tekirdağ from this province are cultivars or types, which are different from each other.

Different authors agree with the existing difficulties to detect intravarietal polymorphism in grapevines (Gogorcena et al., 1993; Sefc et al., 1998). The genetic intravarietal variability has been attributed to two factors: i) a probable polyclonal origin of the varieties and ii) an accumulation of somatic mutations over the centuries increases variability (Ulanovsky et al., 2002).

The RAPD method can solve one of the major problems of varietal identification in grapevines: the existence of homonyms and synonyms, particularly with regard to varieties that have been cultivated for centuries and are widely distributed (Borrego et al., 2002).

DNA fingerprint studies, based on agronomic characteristics, are most likely the cause of mistaken conclusions. Primer or probe screening regions are small compared to genome size in plants, including grapevines, which code the gene regions, not included within the amplified regions. Accordingly, genetic similarity degrees based on molecular markers of the cultivars could emerge independently from the agronomic similarities. On the other hand, the fact that generally there are ecological similarities and parallelism within the population composed of cultivars adapted to a certain geographical region, is another important factor, which should be taken into consideration (Ulanovsky et al., 2002; Ağaoğlu et al., 2006).

The similarity ratios of these local cultivars stated to be synonymous are among the lowest values on the dendogram. In conclusion, it emerges that the region has a very rich and varied clonal structure. The fact that the cultivars stated to be synonymous by the local people and the cultivars having the same name obtained by us and from the National Germplasm Repository Vineyard of Tekirdağ have different genotype stems, most likely because they were, in fact, obtained from different types.

\section{ACKNOWLEDGMENTS}

This research is a part of the project entitled "Molecular Analysis of Southeast Anatolian Region's Grapevine Germplasm by RAPD (random amplified polymorphic DNA) Technique (\#2001-07-11-050)" supported by the Ankara University Research Fund.

\section{REFERENCES}

\footnotetext{
Ağaoğlu YS, Karataş H and Degirmenci D (2006). Molecular characterization of some local (İskilip-Çorum) anatolian grape cultivars (Vitis vinifera L.). 9th International Conference on Grapevine Genetics and Breeding, Udine, Italia. Acta Horticul. 827: 207-210.

Arroyo-Garcia R, Ruiz-Garcia L, Bolling L, Ocete R, et al. (2006). Multiple origins of cultivated grapevine (Vitis vinifera
} 
L. ssp. sativa) based on chloroplast DNA polymorphisms. Mol. Ecol. 15: 3707-3714.

Borrego J, Andres MT, Gomez JL and Ibanez J (2002). Genetic study of Malvasia and Torrontes groups through molecular markers. Am. J. Enol. Vitic. 53: 125-130.

Büscher N, Zyprian E, Bachmann O and Blaich R (1994). On the origin of the grapevine cultivar Müller-Thurgau as investigated by the inheritance of random amplified polymorphic DNA (RAPD). Vitis 33: 15-17.

Ergül A and Ağaoğlu YS (2001). Molecular similarity analysis of some grapevine rootstocks from different nursery in Turkey. J. Agric. Sci. 7: 141-143.

Ergül A, Marasalı B and Ağaoğlu Y.S (2002). Molecular discrimination and identification of some Turkish grape cultivars (Vitis vinifera L.) by RAPD markers. Vitis 41: 159-160.

Fanizza G, Corona MG and Resta P (2000). Analysis of genetic relationships among Muscat grapevines in Apulia (South Italy) by RAPD markers. Vitis 39: 159-161.

Gogorcena Y, Arulsekar S, Dandekar AM and Parfitt DE (1993). Molecular markers for grape characterization. Vitis 32: 183-185.

Karataş H (2005). Molecular Analysis of Diyarbakır Region's Grapevine Germplasm by RAPD (Random Amplified Polymorphic DNA) Technique. Ph.D. thesis (unpublished). Ankara University, Ankara.

Karataş H and Ağaoğlu YS (2008). Genetic diversity among Turkish local grape accessions (Vitis vinifera L.) using RAPD markers. Hereditas 145: 58-63.

Kocsis M, Jaromi L, Putnoky P, Kozma P, et al. (2005). Genetic diversity among twelve grape cultivars indigenous to the Carpathian Basin revealed by RAPD markers. Vitis 44: 91.

Kowach WL (1999). MVSP - A Multivariate Statistical Package for Windows, Ver. 3.1. Kowach. Computing Services, Pentraeth, 133.

Lodhi MA, Daly MJ, Ye GN, Weeden NF, et al. (1994). A simple and efficient method for DNA extraction from grapevine cultivars and Vitis species. Plant Mol. Biol. Rep. 12: 6-13.

Luo S, He P, Zheng X and Zhou P (2002). Inheritance of RAPD markers in an interspecific F1 hybrid of grape between Vitis quinquangularis and V. vinifera. Sci. Horticul. 93: 19-28.

Sefc KM, Regner F, Glössl J and Steinkellner H (1998). Inheritance of RAPD markers in an interspecific F1 hybrid of grape between Vitis quinquangularis and $V$. vinifera. Vitis 37: 20.

This P, Cuisset C and Boursiquot JM (1997). Development of stable RAPD markers for the identification of grapevine rootstocks and the analysis of genetic relationships. Am. J. Enol. Vitic. 48: 492-501.

This P, Lacombe T and Thomas MR (2006). Historical origins and genetic diversity of wine grapes. Trends Genet. 22: 511-519.

Ulanovsky S, Gogorcena Y, Toda FM and Ortiz JM (2002). Use of molecular markers in detection of synonymies and homonymies in grapevines (Vitis vinifera L.). Sci. Horticul. 92: 241-254.

Vidal JR, Coarer M and Defontaine A (1999). Genetic relationships among grapevine varieties grown in different French and Spanish regions based on RAPD markers. Euphytica 109: 161-172.

Ye G-N, Söylemezoglu G, Weeden NF, Lamboy WF, et al. (1998). Analysis of the relationship between grapevine cultivars, sports and clones via DNA fingerprinting. Vitis 37: 31-38. 